\title{
SOME RESULTS IN RETINAL DETACHMENT SURGERY
}

\author{
BY \\ JORGE AND ENRIQUE MALBRÁN \\ Buenos Aires, Argentine
}

A SERIES of 85 surgical cases (Series I), in which we had used Schepens's method of indirect binocular ophthalmoscopy in diagnosis (Schepens, 1952), was described in an earlier paper (Malbrán and Malbrán, 1956), and we have now had a further 18 months' experience of another series of 101 cases (Series II).

In the first series retinal detachment was arbitrarily divided into three groups:

(1) Subclinical detachments, or tears without detachment.

(2) Uncomplicated detachments usually of recent development, in which the retina could be re-applied, at least partially, with rest and binocular bandaging.

(3) Detachments complicated by marked myopia with chorio-retinal and vitreous degeneration, or by persistent vitreous retraction, large or multiple tears, tears with everted edges, fixed folds, uveitis, intra-ocular foreign bodies, or aphakia; cases in which the retina could not be re-applied by means of rest, and cases in which retinal detachment had resisted previous surgery.

In studying Series II (Table I, opposite), this same classification has been followed in principle, but Series II shows a larger proportion of cases in Group 3 and correspondingly fewer in Group 2. This may be due to chance, but may also have been influenced by two important factors:

(i) Our increased experience in pre-operative examination with the indirect binocular ophthalmoscope has led us to include in Group 3 many cases which we might formerly have included in Group 2. This is particularly true in cases of high myopia in which occur tears with everted edges and pars plana cysts (Grignolo, Schepens, and Heath, 1957), and in which biomicroscopy reveals deep alterations of the vitreous stroma with vitreo-retinal retractions at the level of the tear. Schepens's advice has influenced our choice of therapy and has assisted in bringing about an appreciable improvement in the percentage of cures.

(ii) The number of Group 3 cases is larger because the good results obtained in some apparently hopeless cases encouraged us to treat many other "desperate" cases; Table II shows that our efforts were justified.

These "desperate" cases may almost be said to represent a fourth group. They include long-standing detachments (some more than a year old), cases operated on more than once by other surgeons, which showed large tracts of scleral destruction due to excessive diathermy, and cases of past or present uveitis, open trauma, foreign bodies, and vitreous retraction with fixed folds. For the sake of comparison with the previous series, we have included these cases in Group 3, but they are also considered separately further on. 
TABLE I

RESULTS IN THE TWO SERIES COMPARED

\begin{tabular}{|c|c|c|c|c|c|c|c|c|c|}
\hline \multirow[t]{2}{*}{ Series } & \multirow[t]{2}{*}{ Group } & \multirow{2}{*}{$\begin{array}{l}\text { No. of } \\
\text { Cases }\end{array}$} & \multirow{2}{*}{ Therapy } & \multicolumn{2}{|c|}{ Cures } & \multicolumn{2}{|c|}{$\begin{array}{c}\text { Partial } \\
\text { Improvement }\end{array}$} & \multicolumn{2}{|c|}{ Failures } \\
\hline & & & & No. & Per Cent. & No. & Per Cent. & No. & Per Cent. \\
\hline \multirow{6}{*}{ I } & 1 & 10 & $10^{*}$ & 10 & 100 & 0 & 一 & 0 & - \\
\hline & 2 & 30 & $\begin{array}{r}20^{*} \\
5 \dagger \\
5+\end{array}$ & $\begin{array}{r}17 \\
4 \\
5\end{array}$ & $\begin{array}{r}85 \\
80 \\
100\end{array}$ & - & - & $\begin{array}{l}3 \\
1\end{array}$ & $\begin{array}{l}15 \\
20\end{array}$ \\
\hline & & & Total & 26 & 87 & 0 & - & 4 & 13 \\
\hline & 3 & 45 & $\begin{array}{r}5^{*} \\
20^{\dagger} \\
20 \ddagger\end{array}$ & $\begin{array}{r}4 \\
12 \\
10\end{array}$ & $\begin{array}{l}80 \\
58 \\
50\end{array}$ & $\begin{array}{l}1 \\
2 \\
4\end{array}$ & $\begin{array}{l}20 \\
11 \\
20\end{array}$ & $\begin{array}{l}6 \\
6\end{array}$ & $\begin{array}{l}32 \\
30\end{array}$ \\
\hline & & & Total & 26 & 58 & 7 & 16 & 12 & 27 \\
\hline & Total & 85 & - & 62 & 73 & 7 & 8 & 16 & 19 \\
\hline \multirow{7}{*}{ II } & 1 & 21 & $\begin{array}{r}18^{*} \\
3 \dagger\end{array}$ & $\begin{array}{r}18 \\
3\end{array}$ & $\begin{array}{l}100 \\
100\end{array}$ & & & & \\
\hline & & & Total & 21 & 100 & 0 & - & 0 & \\
\hline & 2 & 18 & $\begin{array}{r}3^{*} \\
10 \dagger \\
5 \ddagger\end{array}$ & $\begin{array}{r}2 \\
10 \\
5\end{array}$ & $\begin{array}{r}67 \\
100 \\
100\end{array}$ & - & 一 & 1 & 33 \\
\hline & & & Total & 17 & 95 & 0 & - & 1 & 5 \\
\hline & 3 & 62 & $\begin{array}{r}2 \dagger \\
60_{+}^{\dagger}\end{array}$ & $\begin{array}{r}2 \\
35\end{array}$ & $\begin{array}{r}100 \\
59\end{array}$ & 3 & 5 & 22 & 35 \\
\hline & & & Total & 37 & 60 & 3 & 5 & 22 & 35 \\
\hline & Total & 101 & & 75 & 74 & 3 & 3 & 23 & 23 \\
\hline
\end{tabular}

* Surface diathermy.

\section{Therapy}

† Lamellar resection without polyethylene tube.

$\ddagger$ Scleral resection with partial polyethylene tube, or full-thickness scleral buckling.

\section{Criteria of Cure}

Cure: anatomical and functional restitution of retina.

Partial Improvement: anatomical restitution without functional recuperation, or partial anatomical restitution with obvious improvement in useful vision compared with pre-operative stage.

Failure: Pre-operative condition aggravated or unimproved.

\section{COMPARISON OF THE Two SERIES}

Group 1. Subclinical Detachments and Tears without Detachment (21 cases) - 100 per cent. success was obtained in both series.

Systematic observation of the contralateral eye often reveals the existence of lesions symmetrical with those in the affected eye. This enabled us to 
detect the existence of tears without detachment at the periphery in patients consulting because of other conditions, and so to recommend early surgery. All patients complaining of photopsia and other symptoms of retinal disease and particularly those with degenerative myopia should be closely examined with the indirect binocular ophthalmoscope and Goldmann's three-mirror contact lens.

In 28 of the 31 cases in the two series, light surface diathermy was used. In three cases presenting large tears with vitreous adhering to the edge of the operculum, lamellar resection was performed without inclusion of the polyethylene tube.

Group 2. Uncomplicated Detachments in which the Retina is re-applied spontaneously with Rest and Binocular Bandaging (18 cases).-The percentage of cures increased in the second series from 87 to 95 per cent.

This improvement may be ascribed to better selection of cases, and to greater experience of scleral shortening surgery (lamellar resection with or without inclusion of polyethylene tube). In the first series one case in this group suffered the only serious operative complication (choroidal rupture with vitreous haemorrhage and secondary vitreous retraction), but the rest of the ten cases so treated were cured. In the second series cures were obtained in all the fifteen eyes so treated out of a total of eighteen. The only failure in the group occurred in one of the three cases treated according to the classical method with diathermy.

The greater number of cures obtained in this group by a more frequent use of scleral shortening surgery suggests that this method should not be reserved for "desperate" cases as was previously the custom.

Group 3. Complicated Detachments (62 cases).-This group is the largest in the second series for reasons which have already been given. The degree of success obtained in the two series ( 58 per cent. in the first and 60 per cent. in the second) shows little difference, but Group 3 in the second series includes 23 "desperate" cases of which only six were completely cured and two partially cured (Table II), and this has brought down the percentage for the whole group. Without these very serious cases there were 31 cures in 39 cases ( 79 per cent.).

TABLE II

RESULTS IN “DESPERATE” CASES OF GROUP 3 IN SERIES II

\begin{tabular}{c|c|c|c|c|c|c|c}
\hline \multirow{2}{*}{$\begin{array}{l}\text { No. of } \\
\text { Cases }\end{array}$} & \multirow{2}{*}{ Therapy } & \multicolumn{2}{|c|}{ Cures } & Partial Improvement & \multicolumn{2}{c}{ Failures } \\
\cline { 2 - 7 } & & No. & Per Cent. & No. & Per Cent. & No. & Per Cent. \\
\hline 23 & $\ddagger$ & 6 & 26 & 2 & 9 & 15 & 65 \\
\hline
\end{tabular}

¥ Scleral resection with partial polyethylene tube. 
Many of these "desperate" cases were those of patients who came to us after unsuccessful operations by other surgeons, and the profound alterations in the scleral tissues caused by excessive diathermy gave little hope of success.

Scleral resection, with or without inclusion of the polyethylene tube, or full-thickness scleral buckling, are the only surgical methods used by us in such cases. We are convinced that, at the present stage of knowledge, these techniques should be used at a first operation, and not postponed until the classical methods still recommended by some surgeons have failed.

\section{TECHNIQUE}

In both series, control of the diathermy application was carried out with the indirect binocular ophthalmoscope, which permits accurate localization and reduces the risk of applying diathermy to non-affected regions.

The difficulties which we encountered in replacing the conjunctiva because of damage during protracted surgery was solved by infiltrating subconjunctival physiologic salt-solution at the start of the operation. The oedema so caused assists the preservation of the tissue. The conjunctival incision is always made $1.5 \mathrm{~cm}$. from the sclero-corneal limbus, where the conjunctiva is thicker and more resistant.

When muscle disinsertion is necessary, the muscle is severed by the myostat flush with the sclera, and two sutures are placed on the free edge of the tendon which is then allowed to retract to the floor of the orbit. These two sutures are sufficient guides to find the muscle and re-insert it at the close of the operation.

One of the more usual problems inherent in muscular disinsertion is postoperative heterophoria. To obviate this we use the same manoeuvre as in inferior oblique advancement (Norbis and Malbrán, 1954), originally described by McLean (1949). The region of the sclerotomy is covered with a Tenon's capsule flap, which is attached to the sclera by two or three stitches of virgin silk so that the cut surface of the muscle remains separated from the cut surface of the sclera and adhesions are avoided.

An evacuation puncture is performed by applying surface diathermy and then making the puncture with the current switched off. It is sometimes advisable to enlarge the orifice with a lacrimal puncture dilator. Before tying the resection sutures, we measure the volume of fluid evacuated and if necessary enlarge the orifice. In tying the sutures, particularly after the inclusion of a polyethylene tube, the reduction in eye volume causes more fluid to be expelled. If insufficient liquid is evacuated, air or saline is injected into the vitreous chamber through an area where the retina is still attached, carefully avoiding the risk of vitreous haemorrhage. Injection is carried out on a surface diathermy plaque previously effected under binocular ophthalmoscopic control, as in the case of retinal tears. We prefer the use of saline, which can subsequently be more easily controlled. 


\section{SUMMARY}

The authors' previous communication is recalled in which the advantages were stressed of Schepens's indirect binocular ophthalmoscopy as a method of pre-operative diagnosis and guidance in retinal detachment surgery.

The results obtained in the earlier series are compared with those in the new series, with an analysis of the proportion of different types of case, of the surgical procedures undertaken, and of the technical improvements introduced in the second series.

\section{REFERENCES}

Grignolo, A., Schepens, C. L., and Heath, P. (1957). A.M.A. Arch. Ophthal., 58, 530. MCLean, J. (1949). Arch. Ophthal. (Chicago), 42, 50.

Malbrán, J., and MAlBrán, E. (1956). Boll.'Oculist., 35, 712.

MEYER-SCHWICKERATH, G. (1954). v. Graefes Arch. Ophthal., 156, 2.

Norbis, A., and Malbrán, E. (1954). Arch. Oftal. B. Aires, 29, 413.

SCHEPENS, C. L. (1952). A.M.A. Arch. Ophthal., 47, 593. (1955). Ibid., 54, 143. 